\title{
Pengetahuan tentang nutrisi berhubungan dengan status anemia pada ibu hamil di Puskesmas Sewon II Bantul Yogyakarta tahun 2012
}

\author{
Level of knowledge about nutrition was associated with anemia status of pregnant women in \\ Puskesmas Sewon II Bantul Yogyakarta in 2012
}

Ita Purwanti ${ }^{1}$, Ircham Macfoedz ${ }^{1}$, Wahyuningsih ${ }^{1}$

\begin{abstract}
Background: Anemia is still the main problems in pregnant women. Their anemia status and health condition may influence the growth and the health of fetus. Anemia of pregnant women can lead to some problems, like abortus, birth prematures, infection, antepartum hemorrhage, premature rapture of membrane. Anemia of pregnant women can be influenced by the knowledge level about nutrition and their behavior.

Objectives: To know the relationship between the knowledge about nutrition with anemia status of pregnant women in Puskesmas Sewon II Bantul Yogyakarta in 2012.

Methods: This was descriptive analytical study with cross sectional design. Samples were 50 pregnant women following antenatal care program in Puskesmas Sewon II Bantul Yogyakarta. Data were analyzed by chi-square.

Results: Most of the knowledge level of pregnant women included in good categories, 22 women (44.0\%). Most of pregnant women (33 people, 66.0\%) were not categorized in anemia. Chi-square, $p$-value, and coefficient of contingency were $6.157,0.038(p<0.05)$, and 0.34 , respectively. These proved that there was significant relationship between the level of knowledge about nutrition with anemia status of pregnant women.

Conclusions: There was significant relationship between the level of knowledge about nutrition with anemia status of pregnant women.
\end{abstract}

KEYWORDS: level of knowledge, anemia status, pregnant women

\begin{abstract}
ABSTRAK
Latar belakang: Ibu hamil yang mengalami anemia tentunya menjadi permasalahan jika tidak ditangani dengan baik sebab kesehatan pada ibu hamil sangat penting. Kondisi kesehatan ibu yang terganggu dan mengalami anemia dapat mempengaruhi perkembangan dan kesehatan janin. Dampak anemia pada ibu hamil antara lain: abortus, partus premature, infeksi, perdarahan antepartum dan ketuban pecah dini. Kejadian anemia pada ibu hamil dapat dipengaruhi oleh tingkat pengetahuan tentang nutrisi serta perilaku ibu hamil.

Tujuan: Mengetahui hubungan antara pengetahuan ibu hamil tentang nutrisi dengan status anemia pada ibu hamil di Puskesmas Sewon II Bantul Yogyakarta.

Metode: Penelitian ini merupakan penelitian deskriptif analitik. Rancangan penelitian adalah cross sectional. Sampel dalam penelitian ini adalah ibu hamil yang memeriksa kehamilannya di Puskesmas Sewon II Bantul Yogyakarta sebanyak 50 orang. Analisis data dilakukan dengan analisis Chi-square Hasil: Tingkat pengetahuan ibu hamil tentang nutrisi sebagian besar termasu kategori baik, sebanyak 22(44,0\%). Status anemia ibu hamil sebagian besar tidak menderita anemia yaitu sebanyak 33(66,0\%). Hasil analisis Chi-square diperoleh $X^{2}$ hitung sebesar 6,157 dengan nilai $p$-value sebesar 0,038 $(p<0,05)$, dan nilai koefisien kontingensi sebesar 0,340 yang membuktikan bahwa terdapat hubungan signifikan
\end{abstract}

\footnotetext{
${ }_{1}^{1}$ Program Studi S1 IImu Keperawatan, STIKES Alma Ata Yogyakarta, Jl. Ring Road Barat Daya No 1, Tamantirto, Kasihan, Bantul, Yogyakarta, email: jgdi.almaata@gmail.com
} 
antara tingkat pengetahuan ibu hamil tentang nutrisi dan status anemia ibu hamil di Puskesmas Sewon Bantul Yogyakarta tahun 2012

Kesimpulan: Terdapat hubungan yang signifikan antara tingkat pengetahuan ibu hamil mengenai nutrisi dengan status anemia ibu hamil dengan keeratan hubungan yang rendah di Puskesmas Sewon II Bantul, Yogyakarta tahun 2012.

KATA KUNCI: tingkat pengetahuan, status anemia, dan ibu hamil

\section{PENDAHULUAN}

Anemia dapat didefinisikan sebagai kondisi dengan kadar hemoglobin $(\mathrm{Hb})$ berada di bawah normal. Di Indonesia, anemia umumya disebabkan oleh kekurangan zat besi. Anemia defisiensi besi merupakan salah satu gangguan yang paling sering terjadi selama kehamilan. Ibu hamil umumnya mengalami deplesi besi sehingga hanya memberi sedikit besi kepada janin yang dibutuhkan untuk metabolisme besi yang normal (1). Anemia saat kehamilan memberi pengaruh kurang baik bagi ibu dan janinnya. Pengaruh anemia pada ibu hamil antara lain: abortus, partus premature, infeksi, perdarahan antepartum, dan ketuban pecah dini.

Dinas Kesehatan (Dinkes) Provinsi DIY (2) menyatakan bahwa, di Provinsi DIY prevalensi anemia ibu hamil sangat tinggi yaitu mencapai 73,9\%. Ini berarti dari 100.000 ibu hamil, terdapat 73.900 ibu yang menderita anemia. Prevalensi anemia gizi di Kabupaten Bantul sebesar 42,2\% dari 5.784 ibu hamil, artinya terdapat 2.442 ibu hamil yang mengalami anemia.

Pemerintah Kabupaten Bantul telah memberikan fasilitas pemeriksaan ibu hamil secara gratis serta memberikan tablet Fe, namun ternyata kasus anemia masih sangat tinggi, disebabkan cakupan distribusi tablet $\mathrm{Fe}$ yang masih cukup rendah $(27 \%)$. Kabupaten Bantul menargetkan penurunan kasus anemia hingga 0\%. Defisiensi zat besi merupakan penyebab utama dari anemia, selain perilaku masyarakat terhadap pola konsumsi atau pola makan yang tidak mendukung kesehatan individu, kurang intensifnya penyuluhan kepada masyarakat mengenai pentingnya tablet (Fe), dan tingkat ekonomi serta sosialisasi mengenai pola makan gizi seimbang yang masih rendah $(2,3)$.

Studi pendahuluan pada bulan November 2011 dengan cara memberikan pertanyaan tentang pengetahuan nutrisi kepada 10 ibu hamil yang berkunjung di Puskesmas Sewon II Bantul diperoleh hasil 4 ibu hamil yang kurang mengetahui nutrisi yang baik dan ketika dilihat buku KMS (kartu menuju sehat) atau KIA (kesehatan ibu dan anak) pada ibu hamil ditemukan 5 ibu hamil yang anemia pada kehamilan.

Tujuan penelitian ini adalah untuk mengetahui karakteristik serta hubungan antara pengetahuan ibu hamil tentang nutrisi dengan status anemia pada ibu hamil di Puskesmas Sewon II Bantul Yogyakarta.

\section{BAHAN DAN METODE}

Penelitian ini merupakan penelitian deskriptif analitik dengan menggunakan rancangan penelitian cross sectional. Populasi dalam penelitian ini yaitu seluruh ibu hamil yang memeriksa kehamilanya di Puskesmas Sewon II Bantul Yogyakarta dengan populasi-sebanyak 165 ibu hamil. Teknik pengambilan sampel yang digunakan adalah teknik purposive sampling (4). Lokasi penelitian dilakukan di Puskesmas Sewon II Bantul Yogyakarta pada bulan Mei 2012. Alat yang digunakan untuk mengumpulkan data yaitu kuesioner berisi 33 pertanyaan yang telah diuji validitas dan reliabilitasnya. Sebelum memberikan kuesioner, dijelaskan cara pengisian kuesioner, selanjutnya membagikan informed consent pada responden dan diikuti kuisioner tentang tingkat pengetahuan. Kuesioner diisi langsung oleh responden dan dikembalikan saat itu juga. Instrumen yang digunakan untuk mengetahui kadar $\mathrm{Hb}$ ibu hamil adalah pemeriksaan $\mathrm{Hb}$ dengan metode Sahli, dilakukan oleh petugas labolatorium Puskesmas Sewon II. Metode yang digunakan dalam menganalisis data untuk menguji variabel yang berhubungan dihitung dalam variabel berskala ordinal-menggunakan chi-square.

Variabel bebas pada penelitian ini adalah tingkat pengetahuan tentang nutrisi ibu hamil. Variabel tergantung pada penelitian ini adalah status anemia pada ibu hamil. Variabel pengganggu dalam penelitian ini adalah umur, jarak kehamilan, paritas, sosial ekonomi. 


\section{HASIL}

\section{Karakteristik responden}

Sebanyak 50 ibu hamil trimester III yang memeriksakan kehamilannya saat penelitian memenuhi syarat untuk diteliti dan sesuai dengan kriteria inklusi dan eksklusi. Distribusi frekuensi karakteristik responden dapat dilihat pada Tabel 1.

Tabel 1. Distribusi frekuensi karakteristik usia ibu hamil di Puskesmas Sewon II Bantul tahun 2012

\begin{tabular}{lcc}
\hline \multicolumn{1}{c}{ Karakter } & $\begin{array}{c}\text { Frekuensi Persentase } \\
\text { (n) }\end{array}$ & (\%) \\
\hline Usia (tahun) & & \\
$\leq 20$ & 4 & 8,0 \\
$21-35$ & 41 & 82,0 \\
$>36$ & 5 & 10,0 \\
$\quad$ Jumlah & 50 & 100 \\
Umur kehamilan (bulan) & & \\
7 & 12 & 24,0 \\
8 & 11 & 22,0 \\
9 & 27 & 54,0 \\
Jumlah & 50 & 100,0 \\
Jumlah anak & & \\
0 & 14 & 28,0 \\
1 & 12 & 24,0 \\
2 & 24 & 48,0 \\
Jumlah & 50 & 100,0 \\
Pendapatan per bulan & & \\
SRp 500.000 & 11 & 22,0 \\
Rp 501.000-Rp 1.000.000 & 34 & 68,0 \\
Rp 1.001.000- Rp 1.500.000 & 3 & 6,0 \\
>Rp 1.500.000 & 2 & 4,0 \\
Jumlah & 50 & 100,0 \\
\hline
\end{tabular}

Tabel 1 menunjukkan bahwa sebagian besar ibu hamil di Puskesmas Sewon II Bantul berusia antara 21-35 tahun yaitu sebanyak $41(82,0 \%)$, sedangkan sebagian besar umur kehamilan ibu adalah 9 bulan yaitu sebanyak 27 (54,0\%). Sebagian besar ibu hamil mempunyai 2 anak yaitu sebanyak 24 orang $(48,0 \%)$ dan belum punya anak sebanyak 14 orang $(28,0 \%)$. Penghasilan keluarga per bulan antara Rp 501.000-Rp 1.000.000 yaitu sebanyak $34(68,0 \%)$ dan lebih dari Rp. 1.500 .000 sebanyak $2(4,0 \%)$.

\section{Tingkat pengetahuan responden}

Tabel 2 menunjukkan bahwa sebagian besar ibu hamil yang memeriksakan kehamilan di Puskesmas Sewon II Bantul mempunyai tingkat
Tabel 2. Tingkat pengetahuan ibu hamil mengenai nutrisi di Puskesmas Sewon II Bantul

\begin{tabular}{lcc}
\hline $\begin{array}{c}\text { Tingkat } \\
\text { pengetahuan }\end{array}$ & $\begin{array}{c}\text { Jumlah } \\
\text { (n) }\end{array}$ & $\begin{array}{c}\text { Persentase } \\
\text { (\%) }\end{array}$ \\
\hline Baik & 22 & 44,0 \\
Cukup & 16 & 32,0 \\
Kurang & 12 & 24,0 \\
Jumlah & 50 & 100,0 \\
\hline
\end{tabular}

pengetahuan yang baik mengenai nutrisi yaitu sebanyak $22(44,0 \%)$ dan paling sedikit adalah yang tingkat pengetahuannya kurang sebanyak 12 $(24,0 \%)$.

\section{Status anemia responden}

Tabel 3 menunjukkan bahwa dari 50 ibu hamil yang diperiksa status anemianya, diketahui sebagian besar ibu hamil di Puskesmas Sewon II Bantul tidak mengalami anemia yaitu sebanyak 33 orang $(66,0 \%)$.

Tabel 3. Distribusi frekuensi status anemia ibu hamil di Puskesmas Sewon II Bantul tahun 2012

\begin{tabular}{lcc}
\hline $\begin{array}{c}\text { Tingkat } \\
\text { pengetahuan }\end{array}$ & $\begin{array}{c}\text { Jumlah } \\
\text { (n) }\end{array}$ & $\begin{array}{c}\text { Persentase } \\
(\%)\end{array}$ \\
\hline Anemia & 17 & 34,0 \\
Tidak anemia & 33 & 66,0 \\
Jumlah & 50 & 100,0 \\
\hline
\end{tabular}

Hubungan antara tingkat pengetahuan mengenai nutrisi dengan status anemia ibu hamil

Tabulasi silang dan hasil uji chi square hubungan antara tingkat pengetahuan ibu hamil mengenai nutrisi dengan status anemia pada ibu hamil di Puskesmas Sewon II Bantul disajikan pada Tabel 4.

Ibu hamil dengan pengetahuan tentang nutrisi kategori baik sebagian besar tidak menderita anemia, yaitu sebanyak 14 orang $(42,42 \%)$ dan ibu hamil dengan tingkat pengetahuan kurang sebagian besar menderita anemia yaitu sebanyak 7 orang $(41,18 \%)$. Berdasarkan perhitungan statistik, diperoleh $\chi^{2}$ hitung sebesar 6,517 dengan nilai signifikansi $p$-value sebesar $0,038(p<0,05)$ dan nilai $\chi^{2}$ tabel sebesar 5,591. Dengan demikian dapat dinyatakan ada hubungan yang signifikan antara tingkat pengetahuan dengan status anemia ibu hamil di Puskesmas Sewon II Bantul tahun 2012. Nilai koefisien kontingensi sebesar 0,33 dan lebih kecil dari $0,5(0,33<0,5)$, sehingga hasil variabel dinyatakan kuat. 
Tabel 4. Tabulasi silang dan uji chi square hubungan tingkat pengetahuan dengan status anemia di Puskesmas Sewon II Bantul tahun 2012

\begin{tabular}{|c|c|c|c|c|c|c|c|c|}
\hline \multirow{3}{*}{$\begin{array}{c}\text { Tingkat } \\
\text { pengetahuan }\end{array}$} & \multicolumn{4}{|c|}{ Status anemia } & \multirow{2}{*}{\multicolumn{2}{|c|}{ Total }} & \multirow{3}{*}{$\chi^{2}$} & \multirow{3}{*}{ p } \\
\hline & \multicolumn{2}{|c|}{ Anemia } & \multicolumn{2}{|c|}{ Tidak anemia } & & & & \\
\hline & $\mathbf{n}$ & $\%$ & $\mathbf{n}$ & $\%$ & $\mathbf{n}$ & $\%$ & & \\
\hline Baik & 8 & 47,06 & 14 & 42,42 & 22 & 44,00 & 6,517 & $0,038^{*}$ \\
\hline Cukup & 2 & 11,76 & 14 & 42,42 & 16 & 32,00 & & \\
\hline Kurang & 7 & 41,18 & 5 & 15,15 & 12 & 24,00 & & \\
\hline Total & 17 & 100,00 & 33 & 100,00 & 50 & 100,00 & & \\
\hline
\end{tabular}

* Signifikan

\section{BAHASAN}

Berdasarkan hasil penelitian yang telah dilakukan menunjukkan bahwa sebagian besar ibu hamil di Puskemas Sewon II Bantul memiliki tingkat pengetahuan mengenai nutrisi yang baik, yaitu sebanyak 22 (44,0\%). Hasil tersebut memberikan gambaran tentang tingkat pengetahuan ibu hamil di Puskesmas Sewon II yang cukup tinggi, namun belum dapat diperkuat dengan karakter tingkat pendidikan ibu hamil. Pada penelitian di Puskesmas Pucangsawit dan Sibela di Kecamatan Jebres Surakarta, diketahui tingkat pengetahuan ibu hamil tentang gizi tergolong sedang yang didukung pula oleh tingkat pendidikan yang sedang juga (3). Pengetahuan ibu hamil tentang nutrisi dengan baik dapat mempengaruhi perilaku ibu khususnya berkaitan dengan konsumsi makanan. Dengan pengetahuan yang baik tentunya pola makan dan perilaku ibu dalam mengonsumsi makanan lebih memperhatikan kualitan kandungan gizi dibadingkan kuantitas atau banyaknya makanan yang dikonsumsi. Dengan mengonsumsi makanan yang banyak mengandung nutrisi tentunya dapat meningkatkan kesehatan dan pertumbuhan ibu dan balita. Dengan demikian pengetahuan tentang nutrisi bagi ibu sangat penting.

Menurut Agria (5), ibu hamil harus benarbenar memperhatikan susunan dietnya, terutama mengenai jumlah kalori dan protein yang sangat berguna untuk pertumbuhan janin dan kesehatan ibu. Kekurangan nutrisi dapat menyebabkan anemia, abortus, partus prematurus, perdarahan pasca persalinan, dan lain-lain. Makan berlebihan karena dianggap untuk dua orang (ibu dan janin), dapat menyebabkan komplikasi seperti gemuk, preeklamsi, janin besar, dan lain sebagainya. Ibu hamil memerlukan tambahan beberapa zat untuk pertumbuhan janinnya agar sehat. Makanan di sini diperlukan untuk pertumbuhan janin, plasenta, uterus, buah dada dan kenaikan metabolismenya. Oleh karena itu, masukan zat-zat gizi dalam keadaan hamil harus sangat diperhatikan baik kualitas maupun kuantitasnya. Jika ibu tidak mendapat gizi yang cukup selama hamil, maka bayi yang dikandungnya akan kekurangan gizi. Meski sudah cukup bulan, bayi tersebut lahir BBLR (berat bayi lahir rendah). Oleh karena itu, ibu hamil harus mengetahui jenis makanan yang dianjurkan untuk menjaga kehamilan dan calon bayi.

Status anemia pada ibu hamil yang memeriksakan kehamilan di Puskesmas Sewon II Bantul sebagian besar tidak menderita anemia yaitu sebanyak 33 orang $(66,0 \%)$. Anemia pada ibu hamil merupakan suatu kondisi ibu hamil dengan kadar hemoglobin di bawah $11 \mathrm{~g} \%$, terutama pada trimester I dan trimester III. Wanita hamil dikatakan anemia bila kadar $\mathrm{Hb}$ kurang dari $10 \mathrm{~g} \%$ (4).

Hasil analisis diketahui ibu hamil yang mengalami anemia sebanyak $17(34 \%)$. Ibu hamil yang mengalami anemia menjadi permasalahan jika tidak ditangani dengan baik, sebab kesehatan pada Ibu hamil sangat penting. Kondisi kesehatan ibu yang terggangu dan mengalami anemia dapat mempengaruhi perkembangan dan kesehatan janin. Kurangnya zat besi pada ibu hamil berpengaruh dalam pembentukan hemoglobin sehingga konsentrasinya dalam sel darah merah berkurang. Hal ini akan mengakibatkan tidak adekuatnya pengangkutan oksigen ke seluruh jaringan tubuh. Pada keadaan normal, kebutuhan besi orang dewasa 2-4 g besi, kira- kira $50 \mathrm{mg} / \mathrm{kg}$ BB pada lakilaki, dan $35 \mathrm{mg} / \mathrm{kg}$ BB pada wanita (6), dan hampir dua pertiga terdapat dalam hemoglobin. Absorpsi besi terjadi di lambung, duodenum dan jejunum bagian atas. Adanya erosive esofagitis, gaster, ulser duodenum, kanker pada adenoma kolon akan mempengaruhi absorpsi besi. 
Menurut Manuaba (7), bahaya dapat mengancam ibu yang mengalami anemia, sekalipun tampak janin mampu menyerap berbagai kebutuhan dari ibunya. Dengan anemia, mengurangi kemampuan metabolisme tubuh akan berkurang sehingga mengganggu pertumbuhan dan perkembangan janin dalam rahim. Akibat anemia dapat terjadi gangguan dalam bentuk: abortus, terjadi kematian intrauteri, berat badan lahir rendah, kelahiran dengan anemia, dapat terjadi cacat bawaan.

Umur ibu hamil diketahui sebagian besar berusia 21-35 tahun sebanyak 41 (82,0\%) sedangkan yang berusia kurang dari 20 tahun sebanyak 4 orang $(8,0 \%)$. Umur seorang ibu berkaitan dengan alat-alat reproduksi wanita umur reproduksi yang sehat dan aman adalah 20-35 tahun. Kehamilan di usia $<20$ tahun dan di atas 35 tahun dapat menyebabkan anemia karena pada kehamilan diusia $<20$ tahun secara biologi belum optimal emosinya cenderung labil, mentalnya belum matang sehingga mudah mengalami keguncangan yang mengakibatkan perhatian terhadap pemenuhan kebutuhan kurangnya pemenuhan zat - zat gizi selama kehamilannya. Pada usia $>35$ tahun terkait dengan kemunduran dan penurunan daya tahan tubuh serta berbagai penyakit yang sering menimpa di usia ini. Dengan demikian, dari beberapa ibu hamil yang memiliki usia kurang dari 20 tahun dan lebih dari 35 tahun untuk dapat diberikan informasi berkaitan dengan pola makan dan asupan gizi yang cukup agar tidak mengalami anemia.

Anemia pada ibu hamil dapat dipengaruhi jumlah anak atau paritas. Jumlah anak yang dilahirkan oleh seorang ibu baik lahir maupun mati. Hasil penelitian diketahui jumlah anak, sebagian besar responden dalam penelitian ini mempunyai anak 2 (dua) yaitu sebanyak 24 orang $(48,0 \%)$. Hal ini menunjukkan bahwa sebagian besar ibu hamil di Puskemas Sewon II Bantul sudah mengerti tentang jarak kelahiran yang baik bagi kesehatan ibu. Pemerintah gencar melakukan program KB. Dengan mengikuti program KB dengan baik, yaitu memiliki dua orang anak dan jarak kelahiran yang tepat tentunya kebutuhan gizi dapat terpenuhi dengan baik, sedangkan yang tidak mengikuti program tersebut dengan baik maka pemenuhan gizi akan berkurang dan berisiko terhadap kesehatan bagi ibu dan janin. Ibu hamil yang sering melahirkan mempunyai risiko mengalami anemia pada kehamilan berikutnya apabila tidak memperhatikan kebutuhan nutrisi. Karena selama hamil zat-zat gizi akan berbagai untuk ibu dan janin yang dikandungnya, paritas $>3$ orang berisiko lebih besar untuk menderita anemia.

Ibu hamil yang mengalami anemia dapat dipengaruhi dari faktor sosial ekonomi. Hasil penelitian diketahui pendapatan keluarga dalam satu bulan sebagian besar responden dalam penelitian ini antara Rp 501.000-Rp 1.000.000 yaitu sebanyak 34 orang $(68,0 \%)$. Hal ini mengindikasikan bahwa rata-rata ibu hamil yang memeriksakan kehamilan di Puskemas Sewon II Bantul berasal dari keluarga menengah ke atas, sehingga kebutuhan gizi selama kehamilan terutama kebutuhan zat besi dapat tercukupi. Menurut Manuaba (7), tingkat sosial ekonomi yang rendah akan mempengaruhi seseorang untuk terkena anemia karena jumlah zat- zat gizi tertentu yang dibutuhkan tidak dipenuhi, karena tidak ada uang yang dapat digunakan untuk memenuhi kebutuhan tersebut. Anemia dalam kehamilan merupakan masalah nasional karena mencerminkan nilai kesejahteraan sosial ekonomi masyarakat dan pengaruhnya sangat besar terhadap kualitas sumber daya manusia.

Hasil tabulasi silang menunjukkan bahwa ibu hamil dengan tingkat pengetahuan baik sebagian besar tidak menderita anemia yaitu sebanyak 14 orang $(42,42 \%)$, sedangkan ibu hamil dengan tingkat pengetahuan kurang menderita anemia yaitu sebanyak 7 orang $(41,18 \%)$. Ibu hamil yang memiliki pengetahuan yang baik cenderung tidak menderita anemia, sedangkan ibu hamil yang memiliki pengetahuan yang kurang tentang nutrisi akan berisiko menderita anemia. Hasil penelitian ini mendukung penelitian yang dilakukan Purnamasari Cit. Irmayanti (8) yang menunjukkan ada hubungan antara tingkat pengetahuan tentang anemia dengan kejadian anemia

Berdasarkan perhitungan statistik, diperoleh $\chi^{2}$ sebesar 6,517 dengan nilai signifikansi $p$-value sebesar $0,038(p<0,05)$, sehingga dapat dinyatakan ada hubungan yang signifikan antara tingkat pengetahuan ibu hamil tentang nutrisi dengan status anemia pada ibu hamil di Puskesmas Sewon II Bantul tahun 2012. Nilai koefisien kontingensi sebesar 0,33 lebih kecil dari $0,5(0,33<0,5)$ sehingga hasil tersebut menunjukkan jarak yang cenderung dekat atau hubungan dua variabel dinyatakan kuat. Hasil tersebut dapat memberikan penjelasan 
ibu hamil yang memiliki tingkat pengetahuan baik tentang nutrisi maka perilaku yang baik untuk menjaga kesehatan sehingga dapat mencegah terjadinya anemia.

Menurut Departemen Kesehatan RI (9), ada beberapa cara untuk mencegah anemia, antara lain meningkatkan komsumsi zat besi dari sumber alami, terutama sumber hewani yang mudah diserap (hati, ikan, daging) serta makanan yang banyak mengandung vitamin $\mathrm{C}$ dan vitamin $\mathrm{A}$ (buah-buahan dan sayuran) untuk membantu penyerapan zat besi dan membantu proses pembentukan tersebut. Fortifikasi makanan dapat dilakukan dengan menambahkan zat besi, asam folat, vitamin A dan asam amino esensial pada bahan makanan yang dimakan secara luas oleh kelompok sasaran. Suplementasi besi folat secara rutin selama jangka waktu tertentu antara lain untuk meningkatkan kadar HB secara cepat.

\section{KESIMPULAN DAN SARAN}

Tingkat pengetahuan ibu hamil tentang nutrisi di Puskesmas Sewon II Bantul Yogyakarta sebagian besar dengan kategori baik. Status anemia ibu hamil di Puskesmas Sewon II Bantul Yogyakarta sebagian besar tidak menderita anemia. Ada hubungan yang signifikan antara tingkat pengetahuan ibu hamil mengenai nutrisi dengan status anemia pada ibu hamil di Puskesmas Sewon II Bantul. Hasil penelitian dapat dipergunakan sebagai referensi untuk melaksanakan penelitian lebih lanjut yang berkaitan dengan kesehatan ibu dan janin, dengan melakukan penelitian yang berkaitan dengan faktor internal dan faktor eksternal sebagai upaya peningkatan ilmu pengetahuan, khususnya tentang pengetahuan nutrisi kehamilan dan kenaikan berat badan selama hamil.

\section{RUJUKAN}

1. Moore. Buku pedoman terapi diet dan Nutrisi. II. Jakarta: Hipokrates; 1997.

2. Bantul Dinkes. Profil kesehatan kabupaten bantul daerah istimewa yogyakarta 2009 . Yogyakarata: Depkes RI 1999; 2010.

3. Siwi SS. Hubungan tingkat pengetahuan tentang gizi dengan kadar hemoglobin pada ibu hamil di Kecamatan Jebres Surakarta. J Komun Kesehat. 2010; Volume $1 \mathrm{n}$.

4. Machfoedz. Statistika non parametrik. Yogyakarat: Fitramaya;

5. Agria. Gizi reproduksi. Yogyakarta: Fitramaya Amirudin; 2009.

6. Llewellyn-Jones D. Dasar-Dasar Obstetri dan Ginekologi. Jakarta: Hipokrates; 2002.

7. Manuaba IBG. IImu Kebidanan Penyakit Kandungan dan KB untuk Bidan. Jakarta: EGC; 2003.

8. Irmayanti A. Hubungan antar tingkat pengetahuan tentang anemia dengan kejadian anemia dengan kejadian anemia di puskesmas srandakan bantul yogyakarta. Yogyakarata; 2009.

9. RI D. Startegi penyuluhan gizi seimbang berdasarkan pedoman umum gizi seimbang. Jakarta: Pusat Penyuluhan Kesehatan Masyarakat, Departeman Kesehatan RI; 1998. 